\title{
MARITUS V MULIER: THE DOUBLE PICTURE IN ADULTERY LAWS FROM ROMULUS TO AUGUSTUS
}

\section{Annalize Jacobs*}

In the surviving literature of antiquity social criticism is a male preserve. Not that the men who wrote were in any way disingenuous. They took for granted and frankly admitted that there was one standard of moral behaviour for wives and another for husbands. ${ }^{1}$

Unfaithfulness in a husband - as long as it took account both of the law and of convention was, in general, a concern neither to his conscience nor to the law. That a man's virility might reasonably require greater outlet than his matronly wife could provide was a fact, men held, which should be realistically appreciated, by no one more than by the wife herself. ${ }^{2}$

\section{Introduction}

From Romulus to Augustus the Romans were known for their double set of moral standards for husband and wife. The double picture in spouses' moral behaviour cannot be better portrayed than by the words of Balsdon above. This article investigates this double set of standards, specifically with regard to adultery committed by spouses in Roman marriage from Romulan to Augustan laws. The investigation includes a brief look at the spouses' conduct which resulted in adultery, its consequences and

1 JPVD Balsdon Roman Women. Their History and Habits (London, 1962) at 214.

2 Idem at 215.

* Senior lecturer, Department of Jurisprudence, University of South Africa.

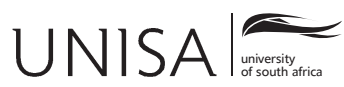


the measures or remedies available to the injured spouse. Finally, possible reasons for these double standards will be searched.

\section{Adultery by spouses in Rome of the kings}

Early Rome was ruled by kings from 753 BC (her traditional founding date) until 510/509 BC. $^{3}$ Under the kings Roman law was primitive, rigid and founded in custom, moral and religious rules of the community embellished by royal decrees (leges regiae). ${ }^{4}$ Although the decrees of the kings were mainly, but not exclusively, concerned with sacred and family law, ${ }^{5}$ the state did not interfere in the private lives and family relations of the Roman familia. ${ }^{6}$ Evidence of Roman law under the kings is limited to few and scattered references by authors who wrote centuries after the laws were said to be in force. ${ }^{7}$ In their research on the marriage laws of Romulus, the first king of Rome, scholars primarily refer to works of Plutarch ${ }^{8}$ and Dionysius of Halicarnassus. ${ }^{9}$

From her foundation, Rome strove to project a perfect image of Roman marriage and family since immorality was a sign of an unstable family and community life. ${ }^{10}$ Dionysius of Halicarnassus praises Romulus in achieving the ideal of a holy and indissoluble marriage by a single law. ${ }^{11}$ One would therefore expect that adultery

3 P du Plessis Borkowski's Textbook of Roman Law (Oxford, 2015) at 1; DH van Zyl History and Principles of Roman Private Law (Pretoria, 1983) at 4-5; A Watson The Law of the Ancient Romans (Dallas, 1970) at 310.

4 For a discussion of sources of law in the archaic period, see Du Plessis (n 3) at 27-29.

5 Watson (n 3) at 10.

6 A Jacobs “Carvilius Ruga v Uxor: A famous Roman divorce" (2009) 15(2) Fundamina. A Journal of Legal History 92-111 at 94-95.

7 G Martin "Earliest Roman divorces: Divergent memories or hidden agendas?" at 1, available at http://cathygary.com/Classics/RomanDivorce.html (accessed 19 Jul 2015).

8 Plutarch (born in AD 46 and died after AD 119) was a Greek biographer, historian, philosopher and essayist. He is primarily known for The Parallel Lives in which he recounts the noble deeds and characters of Greek and Roman soldiers, legislators, orators, and statesmen; and the Moralia, or Ethica, a series of more than sixty essays on ethical, religious, physical, political, and literary topics. Although Plutarch lived during the first and second centuries, he could write biographies of ancient people, such as the one on Romulus, because he had access to material that is no longer available to us. See "Plutarch (Greek biographer)" available at http://global.britannica. com/biography/Plutarch (accessed 19 Jul 2015).

9 Dionysius of Halicarnassus (60 BC-7 BC) was a Greek historian and teacher of rhetoric. His work Antiquitates Romanae (Roman Antiquities) (written in $7 \mathrm{BC}$ ) is one of the most valuable sources on early Roman history. See "Dionysius of Halicarnassus (Greek historian)" available at http:// global.britannica.com/biography/Dionysius-of-Halicarnassus (accessed 19 Jul 2015).

$10 \mathrm{~J}$ Carcopino Daily Life in Ancient Rome. The People and the City at the Hight of the Empire (London, 1962) at 109.

11 Dionysius of Halicarnassus Antiquitates Romanae 225 1-2 (Roman Antiquities, tr B Thayer vol 1, Loeb Classical Library, 1937) at 382, available at http://penelope.uchicago.edu/Thayer/E/Roman/ Texts/Dionysius_of_Halicarnassus/ $2 A^{*}$. html (accessed 19 Jul 2015). 
was taboo in Rome of the kings. However, in the very same text in which Dionysius praises Romulus for stability in Roman marriage, he refers to adultery. This is proof that adultery did occur in early Rome. ${ }^{12}$ Plutarch provides further proof in a biography of Romulus. ${ }^{13} \mathrm{He}$ tells of severe laws that Romulus enacted on divorce. These laws denied a wife the right to divorce her husband, but allowed a husband the right to divorce his wife on grounds of three specific offences. ${ }^{14}$ One of these offences was adultery. The meaning of adultery in this context is clear ${ }^{15}$ and refers to an extra-marital sexual relationship by a married woman with another man who is not her husband. ${ }^{16}$

Romulus did not only prescribe adultery as one of the husband's grounds for divorcing his unfaithful wife, but also spelt out the severe consequences facing her if she committed adultery. In the first place, the ultimate punishment for an unfaithful wife was the death penalty. The husband, assisted by a family council or domestic tribunal, could judge his wife privately and sentence her to death. ${ }^{17}$ Secondly, there was a financial penalty which related to the dowry. If a husband divorced his wife for adultery, the wife or her paterfamilias forfeited the entire dowry with no right to reclaim any of it. The husband, however, incurred no loss of property given as dowry. ${ }^{18}$

Romulan laws undoubtedly established double standards for adultery by spouses. The husband had the right to divorce and kill his wife for adultery with impunity and no financial penalty in terms of the dowry. The wife's position was totally the opposite. She had no rights and no remedies against her unfaithful husband. ${ }^{19}$

12 Adultery did not only occur from as early as the Roman regal period, but even earlier in other ancient laws. See DE Murray "Ancient laws on adultery - A synopsis" (1961) J of Family Law at 89.

13 Plutarch Romulus 223 (The Parallel Lives: "The Life of Romulus", tr B Thayer vol 1, Loeb Classical Library, 1914) at 163, available at http://penelope.uchicago.edu/Thayer/E/Roman/Texts/ Plutarch/Lives/Romulus*.html (accessed 19 Jul 2015). See, also, Watson (n 3) at 1135.

14 Jacobs (n 6) at 98-100. See, esp, 99 n 63 for different interpretations of the specified offences.

15 See A Watson Rome of the XII Tables. Persons and Property (Princeton, 1975) at 33.

16 S Treggiari Roman Marriage. Iusti Coniuges from the Time of Cicero to the Time of Ulpian (Oxford, 1991) at 263; Balsdon (n 1) at 77.

17 Dionysius of Halicarnassus Antiquitates Romanae 225 6; Watson (n 3) at 11. According to scholars a husband had a right to divorce his wife on grounds of adultery. However, he had no free right of killing his wife even if he had justification. An investigation involving the wife's family, and perhaps her husband's, was expected before she could be sentenced to death for adultery. See Watson (n 15) at 44. See, also, EKE von Bóné "The Roman family court (iudicium domesticum) and its historical development in France and the Netherlands" 2013 Osaka University Law Review at 26-31.

18 Plutarch Romulus 22 3. See, also, A Watson "The divorce of Carvilius Ruga" $1965 T v R$ at 45.

19 Watson (n 3) at 35; Treggiari (n 16) at 269-270; Murray (n 12) at 96. 


\section{Adultery by spouses during the Roman republic}

There is no indication by later writings that the first piece of Roman legislation, the Twelve Tables (450/451 BC), ${ }^{20}$ had altered the grounds for divorce (of which adultery was one) or that it had included any law on adultery. It was completely silent on this issue. ${ }^{21}$

During the middle of the republic in the fourth century BC the aediles allegedly could have taken action against men committing adultery and censors might have interfered in adultery cases using censorial discipline. However, these measures have rarely been attested. ${ }^{22}$

According to the jurist Paul, the lex Iulia de adulteriis of Augustus began with an explicit abrogation of several earlier laws. ${ }^{23}$ Unfortunately, we know nothing about the contents of these laws. ${ }^{24}$ No general law on adultery is attested in the time of the republic which changed the meaning of adultery or the position of the spouses. It appears that the double standards for spouses' moral behaviour of Romulan laws still prevailed as portrayed by the literary sources referred to above. Aulus Gellius ${ }^{25}$ provides evidence of this in his Noctes Atticae ${ }^{26}$ where he summarises a speech of Marcus Cato, ${ }^{27}$ On the Dowry (De Dote), delivered towards the end of the second century BC. From Cato's speech it appears that adulterous women, specifically wives, were still treated harshly. If a husband caught his wife red-handed committing adultery, he could kill her with impunity without a trial (presumably that of the family council). ${ }^{28}$ However, if he decided to divorce her, he could judge her, as a

20 Van Zyl (n 3) at 24-26.

21 Watson (n 15) at 32 33-34. See, also, M Carnelley "Adultery laws: Comparing the historical developments of South African common law principles with those in English law" (2013) 19(2) Fundamina $185-211$ at $187 \mathrm{n} 21$.

22 Treggiari (n 16) at 275-277.

23 Paul Coll 42 1-2; D Wardle "Suetonius on the legislation of Augustus (Aug 34)" (2015) 21(1) Fundamina $185-204$ at 188.

24 P Csillag The Augustan Laws on Family Relations (Budapest, 1976) at 176.

25 Aulus Gellius ( $c a 125$ AD-after 180 AD) was a Latin author and grammarian who lived in the second century AD. He focused his interests on ancient times. In his Noctes Atticae (Attic Nights) many fragments of lost works are preserved. See "Aulus Gellius (Latin rethorician)" available at http://global.britannica.com/biography/Aulus-Gellius (accessed 22 Jul 2015).

26 Aulus Gellius Noctes Atticae 1023 2-5. See, also, Watson (n 3) at 35. According to Von Bóné (n 17) at 28, this text was probably written between $\mathrm{AD} 146$ to $\mathrm{AD} 158$ during the reign of Antoninus Pius (AD 131-161).

27 Marcus Porcius Cato (234-149 BC), also known as Cato the Censor or Cato the Elder, was a Roman statesman during the Roman republic with oratorical and legal skills. See "Marcus Porcius Cato (Roman statesman [234-149 BC])" available at http://global.britannica.com/biography/ Marcus-Porcius-Cato (accessed 22 Jul 2015).

28 See A Watson Roman Private Law around 200BC (Edinburgh, 1971) at 23 who notes that no evidence indicates that this right to punishment was extended to the wives sine manu. See, also, PE Corbett The Roman Law of Marriage (Oxford, 1930) at 128. 
censor would, and condemn her. The wife could still not dare to lay a finger on her adulterous husband because the law did not permit it. ${ }^{29}$ In a nutshell, the position of the spouses by the end of the second century could be summarised as follows.

\section{Position of the unfaithful wife}

Cato's speech, which Gellius quoted literally, is clear on the husband's right to kill his wife if he caught her red-handed committing adultery. However, it lacks precision about the identity of the censor, the nature of the family council, and the wife's punishment in the case of the husband divorcing his wife..$^{30}$

Further research indicates that Cato compares the authority of the husband towards his wife with that of a magistrate towards his citizens, hence the husband judged his wife and acted like a censor. ${ }^{31}$ The husband did not necessarily judge his wife alone, though. A family council or tribunal investigated the adultery of the wife and judged her in private. ${ }^{32}$ The council could consist of the unfaithful wife's husband and/or paterfamilias, members of the wife's and/or husband's familia or even friends. ${ }^{33}$ The council could inflict severe punishment such as the death penalty and exile. If this appeared to be too grave, divorce could also be used to get rid of her. In the case of divorce, there were always financial penalties realised at the expense of the dowry. An unfaithful wife could, for example, forfeit one sixth of the dowry. ${ }^{34}$ She could also be returned to her father. ${ }^{35}$

\section{Position of the unfaithful husband}

The position of the unfaithful husband was the exact opposite of the unfaithful wife's. The wife had no right to immediately take revenge and kill her husband. She could not raise her hand against him; in fact, she could not lay a finger on him. ${ }^{36}$ She

29 Aulus Gellius Noctes Atticae 1023 5; Treggiari (n 16) at 268-270.

30 Aulus Gellius Noctes Atticae 1023 4. See, also, J Zablocki "The image of a Roman family in Noctes Atticae by Aulus Gellius" (1996) 2 Pomoerium at 41-42.

31 Von Bóné (n 17) at 28-29.

32 Csillag (n 24) at 177; Von Bóné (n 17) at 28-29.

33 Dionysius of Halicarnassus Antiquitates Romanae 225 6; Aulus Gellius Noctes Atticae 10 23 2-5; Valerius Maximus Memorabilia 29 2; 63 8-9; Livius Ab Urbe Condita 1 58. See, also, Treggiari (n 16) at 268-269 461-462; Csillag (n 24) at 177; Von Bóné (n 17) at 28-31; Watson (n 15) at 34-35 43-44; JF Gardner Women in Roman Law and Society (London, 1996) at 121; A Jacobs ' $n$ Ondersoek na die Regsbeskerming van die Vrou se Huweliksverhouding tydens die Klassieke Romeinse Reg (Pretoria, 1997) at 138.

34 Dionysius of Halicarnassus Antiquitates Romanae 225 6; Plinius Naturales Historiae 1414 8990; Ulpianus Regulae 6 12. See, also, Corbett (n 28) at 128-131 226-227; Gardner (n 33) at 121123; Csillag (n 24) at 177; Jacobs (n 33) at 138-139; Balsdon (n 1) at 188.

35 Balsdon (n 1) at 77.

36 Aulus Gellius Noctes Atticae 10235. 
could not bring him before a family council. In the early republic divorce was also not an option. ${ }^{37} \mathrm{He}$ could commit adultery without any fear of severe punishment or financial penalties.

Significant changes in Roman law of marriage and divorce which occurred during the last two centuries of the republic resulted in the idea of free marriage and divorce, and both husband and wife now had unlimited right to divorce. No specific grounds for divorce existed. Both spouses had the right to divorce on ground of adultery with some financial implications regarding the dowry. ${ }^{38}$

\section{$4 \quad$ Adultery by spouses during the Augustan Empire}

\section{Introduction}

When Augustus became the first Roman emperor in $27 \mathrm{BC}$, the moral depravity of the Roman society was still enormous and shook the carefully-guarded family of the ancient Romans. Roman marriage and especially the Roman family were facing a crisis. Augustus decided to promulgate laws in order to launch an attack against the lack of moral standards. The purpose of these laws was not only to curb the immoral behaviour (eg, the high divorce rate) or sexual misconduct of society (eg, adultery), but also to restore the ideal picture of the ancient Roman family. ${ }^{39}$ Moral reforms therefore marked the years between 18 and $16 \mathrm{BC}$. The lex Iulia de adulteriis coercendiis, Augustus's so-called remarkable piece of social engineering, ${ }^{40}$ was passed in $18 \mathrm{BC} .{ }^{41}$ These reforms were radical since they allowed the state to interfere in the private lives and family relations of the Romans, and this was contrary to the then existing custom of dealing with adultery within the privacy of the family without state interference. ${ }^{42}$

The lex Iulia remained the main source of law dealing with the adultery of Roman spouses during the early empire. ${ }^{43}$ It was amended in AD 9 by the lex Papia Poppaea, but thereafter fell mostly in disuse. ${ }^{44}$ It revived with its re-incorporation

37 Jacobs (n 6) at 101.

38 C 8382 (Imp Alexander Severus); Paulus D 451134 1. See, also, Kaser Das Römische Privatrecht vol 1 (München, 1971) at 326; Watson (n 28) at 23; Du Plessis (n 3) at 128-129 132.

39 Kaser (n 38) at 318-319; Corbett (n 28) at 133; Csillag (n 24) at 175.

40 Roman authors and modern scholars differ in their views regarding the success of the lex Iulia de adulteriis. See Tacitus Annales 25; Seneca De Beneficiis 333 4; Plutarch Moralia 493 E; Kaser (n 38) at 318-319; Nörr "The matrimonial legislation of August: An early instance of social engineering" (1981) 16 The Irish Jurist at 350-364; Treggiari (n 16) at 294-298.

41 Suetonius Augustus 34 1; Du Plessis (n 3) at 129-130; Csillag (n 24) at 175-176; Corbett (n 28) at 133.

42 L Betzig "Roman monogamy" (1992) 13 Ethology and Socio-biology at 365-366; TAJ McGinn Prostitution, Sexuality and the Law in Ancient Rome (New York, 1998) at 140.

43 Du Plessis (n 3) at 130.

44 Carnelley (n 21) at 188. 
into the Sententiae of Julius Paulus Prudentissimus (Paulus) ${ }^{45}$ and later the Corpus iuris civilis. ${ }^{46}$

Unfortunately, Augustus's lex Iulia de adulteriis was not preserved in its entirety. Consequently, the contents of the lex have to be pieced together from fragments scattered over a variety of sources. ${ }^{47}$ There are mainly four surviving legal sources that contain information relating to adultery: Justinian's Digest 485 "Ad legem luliam de adulteriis coercendis"; 48 Justinian's Codex 99 "Ad legem luliam de adulteriis et de stupro" (their primary sources are the commentaries of later jurists which include some of the original words used in the lex Iulia de adulteriis coercendis); Justinian's Novellae 117 and 134; and the Sententiae of Paul 226 "De adulteriis" (which clarify certain points on which the other sources remain silent) ${ }^{49}$ Scholars regard jurists' commentaries to be ambiguous in some instances, but agree that they are generally in accordance with the content of the lex Iulia. ${ }^{50}$

To piece the law on adultery together from the different fragments is difficult, and more than often confusing. ${ }^{51}$ One of the lacunae in the remaining fragments of the lex Iulia is the lack of an original or accurate definition of adultery. However, it is accepted that adultery referred to extramarital sexual relations with or by married women..$^{52}$ In terms of the lex Iulia de adulteriis, adultery was for the first time in Roman legal history a public offence with criminal penalties. Yet, it appears that the double standards of early Roman law prevailed. A wife's adultery was always a crime, but a husband's adultery was a crime only if committed with married women..$^{53}$

\section{Position of the unfaithful wife}

A wife committed adultery if she had a sexual relationship with any other man than her husband. Her adultery was, as said above, always a crime and could be tried by a

45 This document is generally referred to as the Opinions of Julius Paulus Addressed to his Son (hereunder referred to as Paulus Sententiae). He lived during the second to the third century AD. The references hereunder are to Book 2 in SP Scott (tr) The Civil Law (Cincinnati, 1932), available at http://webu2.upmfgrenoble.fr/DroitRomain/Anglica/Paul2-Scott.htm (accessed 28 Jul 2015).

46 Carnelley (n 21) at 188.

47 Csillag (n 24) at 178-179.

48 All references to D 485 in this article are from T Mommsen, P Krueger \& A Watson (eds) The Digest of Justinian vol 4 (Philadelphia, Pa, 1985).

49 A Richlin "Approaches to sources on adultery in Rome" in HP Foley (ed) Reflections of Women in Antiquity (New York, 1986) at 380-381.

$50 \quad$ Idem at 381.

51 In view of the lack of legal sources, scholars have to rely on literary sources, but always have to keep in mind the gender of the authors and also the different genres of these sources. See Richlin (n 49) at 379ff; Csillag (n 24) at 199-202; Gardner (n 33) at 121ff.

$52 \mathrm{~J}$ Evans Grubbs Law and Family in Late Antiquity. The Emperor Constantine's Marriage Legislation (New York, NY, 1999) at 203; Corbett (n 28) at 141.

53 Inst 418 4. See, also, A Mette-Dittman Die Ehegesetze des Augustus (Stuttgart, 1991) at 34; Csillag (n 24) at 179-180; Treggiari (n 16) at 278-279. 
permanent public criminal court (quaestio perpetua de adulteriis). These courts were specially established to deal with adultery. In these courts praetores were presiding officers, aediles prosecuted the offenders and strict prescriptions and procedures had to be followed. These public criminal courts brought to an end the use of family councils. The outcome of a trial could result in serious consequences for the wife as the discussion below illustrates..$^{54}$

\section{Death}

The ultimate punishment for an unfaithful wife was death. A father ${ }^{55}$ could kill his married daughter (if she was still under his power) and her lover if they were caught committing adultery in his house or her husband's house. He had to kill both his daughter and her lover irrespective of his status, ${ }^{56}$ because if he killed only one of them, he could be charged with murder. ${ }^{57}$

The husband's rights to kill his unfaithful wife were more limited. He could not legally kill his wife $\mathrm{e}^{58}$ but he could kill her lover, if he was of inferior status ${ }^{59}$ and he caught them red-handed committing adultery in his own home. ${ }^{60}$ If the husband decided to take revenge and kill his wife and her lover, he could be charged with murder. However, in casu, he faced more lenient punishment than other murderers, such as a sentence of exile or hard labour, because his act of revenge was regarded as "a result of great annoyance and just suffering". ${ }^{61}$

\section{Divorce and prosecution}

An unfaithful wife could face divorce and then prosecution for adultery. In terms of the lex Iulia divorce of the unfaithful wife was a prerequisite of her prosecution.

54 Corbett (n 28) at 133; Gardner (n 33) at 123; Richlin (n 49) at 381399 n 5.

55 In this context, "father" refers to a paterfamilias, either an adoptive or natural father, who himself was not under patria potestas. See Papinianus D 485 23(22); Paulus Sententiae 226 1-2.

56 Ulpianus D 485 22(21) and D 485 24(23); Papinianus D 48523 (22) 2, 4; Macer D 48533 (32) pr; Paulus Sententiae 226 1. See, also, Mette-Dittman (n 53) at 35-36; Gardner (n 33) at 129-130; Du Plessis (n 3) at 115130.

57 McGinn (n 42) at 146; Du Plessis (n 3) at 115130.

58 Paulus Sententiae 2 26 2, 4 and 7; Du Plessis (n 3) at 130.

59 In this context, "inferior status" refers to lovers belonging to a particular category of persons, namely slaves, clutches, singers, dancers, convicted offenders and liberti of the man or woman. See Macer D 48525 (24) pr; Paulus Sententiae 2264 and 226 7; Du Plessis (n 3) at 130; Carnelley (n 21) at 190.

60 Ulpianus D 48522 and D 4852 5-7; Papinianus D 485 12(11) 13; Macer D 485 25(24). See, also, Mette-Dittman (n 53) at 35-36; Gardner (n 33) at 129-130; Du Plessis (n 3) at 130.

61 Paulus Sententiae 226 5. For exile, see C 994 (Imp Alexander A Iuliano); for hard labour, see Papinianus D 485 39(38) 8. See, also, Du Plessis (n 3) at 127 who notes that they were often not even convicted. 
Since a husband could not legally kill his wife caught in an act of adultery, the law forced him to divorce her before witnesses and then to prosecute her for adultery, ${ }^{62}$ because he could not prosecute her for adultery if they were still married. ${ }^{63}$ The law prescribed strict requirements and time frames ${ }^{64}$ within which the husband had to divorce and prosecute his wife after her adultery, as well as severe punishment if he did not adhere to it. If he failed to act within the required timeframes, he was guilty of the crime pimping (lenocinium) which was punished in a similar way to adultery. ${ }^{65}$ If he refused to divorce or prosecute her, despite the fact that he caught her red-handed in his house and her lover is still alive, ${ }^{66}$ he could be punished with pandering. ${ }^{67}$

If the husband did not prosecute his wife, her paterfamilias could proceed with the prosecution. If he failed to do so, any member of the public older than twenty five could do so within a period of four months, resulting in the adulteress being brought out in public and humiliated. ${ }^{68}$

\section{Other penalties}

An unfaithful wife convicted of adultery could face severe penalties. The list of penalties include: infamia, which included loss of citizenship ${ }^{69}$ and loss of dignity (the lowering of her status to that of a prostitute) $;^{70}$ loss of a third of her property (separate estate) and confiscation of half of her dowry; ${ }^{71}$ exile to an island other than her lover; ${ }^{72}$ loss of the right to contract a valid marriage again; ${ }^{73}$ loss of part of her right to inherit; ${ }^{74}$ and inability to testify in court. ${ }^{75}$

62 Paulus Sententiae 226 6; Balsdon (n 1) at 77.

63 C 9911 (Imp Alexander A Norbano).

64 Within three days of the wife's adultery, the husband had to publicly name the adulterer and the place of adultery. Within sixty days of divorce the husband had to prosecute his wife. Scaevola D 485 15(14) 2; C 996 (Imp Alexander A Sebastiano); Paulus Sententiae 226 6. See, also, Du Plessis (n 3) at 129-130; Balsdon (n 1) at 78; Carnelley (n 21) at 190-191.

65 Ulpianus D 48522 and D 4852 5-7; Papinianus D 48512 (11)13; Macer D 48525 (24) 1; Paulus Sententiae 2266 and 26 8; Carnelley (n 21) at 190-191.

66 The husband had no obligation to prosecute the lover, notes McGinn (n 42) at 178.

67 Paulus Sententiae 226 8; Ulpianus D 48522 and D 485 30(29); C 992 (Impp Alexander et Antoninus AA Cassiae).

68 Ulpianus D 48 5 4 C 996 (Imp Alexander A Severus); Du Plessis (n 3) at 130; Betzig (n 42) at 366.

69 Du Plessis (n 3) at 129.

$70 \quad$ McGinn (n 42) at 143147156 238-239.

71 Paulus Sententiae 226 14; McGinn (n 42) at 141-142.

72 Idem. Cf McGinn (n 42) at 143.

73 Balsdon (n 1) at 77.

74 McGinn (n 42) at 143.

75 Papinianus D 225 13-14; Paulus D 225 18. See, also, Csillag (n 24) at 197. 


\section{Position of the unfaithful husband}

The position of the unfaithful husband was still much more favourable than that of the unfaithful wife. He committed adultery if he had a sexual relationship with another married woman, ${ }^{76}$ but in most cases escaped punishment for his unfaithfulness to his own wife. ${ }^{77}$

\section{Death}

No evidence could be found that a wife or her paterfamilias had the right to punish her unfaithful husband with death.

\section{Prosecution}

A wife could not prosecute her unfaithful husband for adultery since the law did not allow her to act as an accuser in public proceedings. ${ }^{78}$ However, her father, family or a third person could prosecute her unfaithful husband on her behalf, if he committed adultery with a married women whose father or husband did not prosecute him within the prescribed period. ${ }^{79}$

\section{Other penalties}

If the unfaithful husband was convicted for adultery, he could face the following penalties: infamia which could include the lowering of his status, humiliation and emasculation; ${ }^{80}$ relegation to an island other than his lover; and loss of half of his property. ${ }^{81}$

76 C 991 (Impp Severus et Antoninus AA Cassiae).

77 It should be noted, however, that an unfaithful husband could, as lover, be punished and prosecuted for adulterium (adultery) with another man's wife or for stuprum (dishonorable vices) with honorable unmarried women, widows and men. His extramarital relationship with a slave, prostitute or women in terms of the legal and social definitions of respectability, did not constitute adultery according to Roman law, and could not be prosecuted. See Corbett (n 28) at 141; Csillag (n 24) at 197.

78 Pomponius D 482 1; C 991 (Impp Severus et Antoninus AA Cassiae); Corbett (n 28) at 141-142; Csillag (n 24) at 197; Balsdon (n 1) at 77.

79 Ulpianus D 4852 pr, D 4852 8-9, D 485 4, D 485 16(15) 5, D 485 27(26). See, also, Richlin (n 49) at 382402 n 16; Gardner (n 33) at 127-128.

80 Papinianus D 485 23(22) 3: "A man who has the right to kill an adulterer has all the more right to inflict humiliation on him." J Walters ("Invading the Roman body: Manliness and impenetrability in Roman thought" in JP Hallett \& MB Skinner (eds) Roman Sexualities (Princeton, NJ, 1997) 29-43 at 3943 50-51) interprets this to include beatings, rape and castration.

81 Paulus Sententiae 26 24; Csillag (n 24) at 198. 


\section{Divorce}

Divorce (repudium) was indeed the only certain remedy for the wife against her unfaithful husband as both spouses had the right to divorce during the time of Augustus. No grounds for divorce existed. Therefore the wife could divorce her husband on grounds of adultery and he then faced financial penalties regarding the dowry. ${ }^{82}$

\section{$5 \quad$ Reasons for double standards}

\section{Social role and activities of wife as materfamilias and matrona $^{83}$}

When a man married, he changed from a caelebs (single man) to a maritus (husband). If he was a paterfamilias before marriage, he was no more of a paterfamilias afterwards. However, when a woman married for the first time, she changed from a virgo (virgin) and became a mulier (wife), a change which Romans regarded as significant, natural and auspicious. She was now a wife and materfamilias of the household, and to the outside world a matrona. Her life was dominated by her position of authority in the household, her potential motherhood and a strict code of moral behaviour that required dignitas (dignity), pudor (modesty) and pudicitia (sexual chastity). It was this strict code of moral behaviour which differentiated the wife's role in society from that of her husband's. She had to remain chaste and behave in a way that would not draw attention to her or bring disrepute to her husband. The husband's life continued much as before, except that he now had the support of a wife. She was possibly involved in his business, the running of his estates and his political career, and socialized with him. ${ }^{84}$

Adultery was one of the gravest offences a wife could commit ${ }^{85}$ and indeed contrary to the code of conduct expected from the materfamilias and matrona. It was a crime that brought shame on her husband's honour ${ }^{86}$ since her child with a stranger would become part of the household of her unsuspecting husband ${ }^{87}$ The social role and activities of the wife as materfamilias and matrona were reason enough for the double standards in spouses' moral behaviour.

82 Kaser (n 38) at 326; Watson (n 28) at 24.

83 For a discussion on the use of and difference between "materfamilias" and "matrona", see Treggiari (n 16) at 34-35 278-280.

84 Dionysius of Halicarnassus Antiquitates Romanae 224 1-2 and 226 1; Treggiari (n 16) at 414; D’Ambra Roman Women (New York, 2007) at 17-18 46 49; M Johnson \& T Ryan Sexuality in Greek and Roman Society and Literature: A Sourcebook (New York, 2005) at 6-8; G MacCormack "Wine drinking and the Romulan law of divorce" 1975 (10) The Irish Jurist at 172-173.

85 C 991 (Impp Severus et Antoninus AA Cassiae); Carnelley (n 21) at 189.

86 D'Ambra (n 84) at 49.

87 Papinanus D 48561 . See, also, Carnelley (n 21) at 189, esp n 42. 


\section{A male-dominant Roman society}

Perhaps another reason was the male-dominant Roman society. Sources were written by men and from a male's perspective.$^{88}$ Social criticism in the surviving literature of antiquity was a male reserve. ${ }^{89}$ However, evidence exists that not all men admitted and took for granted that such a set of double standards can simply be accepted as tradition. There were jurists, writers and poets who deplored this licensed privilege of a husband. Musonius Rufus (AD 30-100), a Roman eques, who advocated moral values, strongly opposed such a double standard. ${ }^{90}$ The famous jurist Ulpian ${ }^{91}$ believed that it was most unfair for a man to require from a wife the high moral values and chastity that he does not himself practise. And Plutarch stated that "[a] husband who bars his wife from the pleasures in which he himself indulges is like a man who surrenders to the enemy and tells his wife to go on fighting". ${ }^{92}$

\section{Hidden agendas of Roman authors}

Treggiari ${ }^{33}$ intimates an attempt by Roman authors, for example Dionysius of Halicarnassus, to draw a parallel between Romulus and Augustus in support of the Augustan laws. Martin notes that these authors lived shortly before, during or shortly after the Augustan reforms in family law and their writings may be a response to mostly in favour of - these laws. He even goes as far as to argue that "their 'memories' of the past are not only selective, but in some cases clearly fabricated to support their views". ${ }^{44}$ Are the hidden agendas of Roman authors perhaps another reason?

\section{Conclusion}

From Romulus to Augustus adultery occurred and was considered to be the extramarital relationship by or with married women. According to the law of this period, the unfaithful wife's adultery was always a crime, but the husband's only if committed with a married woman. The unfaithful wife faced prosecution with severe punishment, such as death and exile. She also faced financial penalties related to the dowry. If death or exile was too grave she was divorced, faced infamia or lost certain of her limited rights. In early law she was privately judged by a family council. By the time of August she was prosecuted in a public criminal court. The unfaithful husband escaped all of this. The only certain remedy for the wife since

88 Balsdon (n 1) at 25 214; Foley (n 49) at xi; S Dixon Roman Family (London, 1992) at 69.

89 See, in this regard, Balsdon (n 1) at 209-223; Richlin (n 49) at 380.

90 Treggiari (n 16) at 220-223.

91 D 485 14(13) 5.

92 Plutarch Moralia 145A, as translated by Balsdon (n 1) at 218.

93 (n 16) at 211-214.

94 (n 7) at 8. 
the late republic was divorce, a mere private self-help measure. The other remedy in Augustan law, was the right which her father or family had to prosecute her husband if his lover's father or family did not prosecute him. A double set of standards in the case of spouses' adultery existed in adultery laws from Romulus to Augustus which undoubtedly favoured the unfaithful husband. And the social role of the Roman materfamilias and matrona in a male-dominant society appears to have justified these double standards.

\section{ABSTRACT}

This article investigates the double set of standards applicable to Roman spouses' adultery. It argues that adultery occurred from Romulus to Augustus and was always considered to be the extramarital relationship by or with married women. It examines the position of both the unfaithful husband and the unfaithful wife with regard to conduct which resulted in adultery, its consequences and the measures or remedies available to the injured spouse. Furthermore, the article argues that the social role of the Roman materfamilias and matrona, the Roman male-dominant society and the hidden agendas of Roman authors could be seen as possible reasons for the different moral principles. The article concludes by pointing out that the unfaithful husband was in a much more favourable position than the unfaithful wife and that the social role of the Roman materfamilias and matrona in a male-dominant society appears to have justified these double standards. 